\title{
KEDUDUKAN NOTARIS YANG MEMILIKI JABATAN STRUKTURAL DI PERGURUAN TINGGI
}

\author{
Roosalina Kartini; Rusdianto Sesung \\ Magister Kenotariatan Fakultas Hukum Universitas Narotama Surabaya \\ Jl. Arief Rahman Hakim 51 Surabaya \\ Email: roosalinakartini1977@gmail.com; rusdianto@narotama.ac.id
}

\begin{abstract}
Characteristic of Notarial as an esoteric science brings consequence which makes this science cannot be taught to person who does not possess knowledge within this field. In order to produce high quality candidates of notary public, Some University as educational agency of notarial science provides structural position for notarial practitioner to become lecturer in Notarial Master Program at the University. This approach is conducted to adjust between learning curriculum of notarial science and learning outcome of the graduates as notary public. But this approach is obstructed with rules that are enacted in Regulation of Notary Public (Undang-Undang Jabatan Notaris) which prohibit notary public to hold double positions as lecturer coupled with practitioner.
\end{abstract}

Keywords: Notary Public, Double Positions, Structural Position.

\begin{abstract}
Abstrak
Karakteristik ilmu Kenotariatan sebagai ilmu yang esoterik membawa konsekuensi bahwa ilmu tersebut tidak bisa diajarkan oleh orang yang tidak memahami seluk beluk dunia kenotariatan. Demi menghasilkan calon Notaris yang berkualitas beberapa Perguruan Tinggi penyelenggara program Magister Kenotariatan memberikan jabatan struktural kepada praktisi Notaris yang menjadi Dosen pengajar di Perguruan Tinggi tersebut agar mampu menyesuaikan kurikulum pembelajaran dengan kebutuhan praktek nantinya. Kondisi tersebut dihadapkan dengan ketentuan dalam Undang-Undang Jabatan Notaris yang mengatur larangan rangkap Jabatan Notaris.
\end{abstract}

Kata kunci : Notaris, Rangkan Jabatan, Jabatan Struktural.

\section{LATAR BELAKANG MASALAH}

Kedudukan Notaris sebagai suatu jabatan yang terhormat dan memiliki peran sangat penting dalam masyarakat tentunya mengharuskan siapa yang memangku jabatan tersebut memiliki kualitas yang mumpuni baik secara keilmuan maupun kepemimpinan. Ilmu pengetahuan khususnya di bidang hukum harus benar- benar dipahami oleh Notaris secara mendalam. Hal tersebut tercermin dari salah satu syarat pengangkatan Notaris yang disebutkan dalam Pasal 3 huruf UUJN adalah "Berijazah Sarjana Hukum dan lulus jenjang strata dua Kenotariatan".

Adanya kualifikasi khusus tentang pendidikan minimal bagi syarat pengangkatan Notaris seperti yang telah 
disebutkan diatas yaitu Sarjana Hukum dan jenjang strata dua kenotariatan yang lazim disebut dengan Magister Kenotariatan bukan tanpa alasan, hal tersebut ditujukan agar Notaris menjadi sosok yang mampu menyampaikan kebenaran dan memberikan keadilan bagi pihak yang membutuhkan jasanya, bukan sekedar memberikan kepastian hukum semata.

Disamping itu, perlunya pendidikan khusus dan kemampuan yang memadai sebelum diangkat sebagai Notaris adalah disebabkan karena pelaksanaaan tugas jabatan Notaris merupakan pelaksanaan tugas jabatan yang esoterik, yang berarti bahwa hal tersebut harus dipelajari atau dimengerti secara khusus. Sifat esoterik dalam dunia kenotariatan tersebut membuat pendidikan tentang Ilmu Kenotariatan tidak bisa diajarkan oleh orang yang tidak memahami seluk beluk dunia kenotariatan, sehingga dalam pendidikan Magister Kenotariatan diupayakan sebisa mungkin yang menjadi Dosen atau Pengajar adalah dari kalangan praktisi Notaris yang telah memenuhi kualifikasi akademik minimal lulusan program Magister sebagaimana dinyatakan dalam Pasal 46 ayat (2) huruf a Undang-Undang Nomor 14 Tahun 2005 Tentang Guru dan Dosen (selanjutnya ditulis UU Guru dan Dosen).Disebutkan dalam undang-undang nomor 12 tahun
2012 tentang pendidikan tinggi disebutkan dalam pasal 10 ayat (2) huruf $f$ bahwa ilmu hukum termasuk dalam rumpun ilmu terapan artinya bahwa ilmu hukum merupakan rumpun ilmu pengetahuan dan teknologi yang mengkaji dan mendalami aplikasi ilmu bagi kehidupan manusia sehingga setara dengan ilmu lain seperti kesehatan, lingkungan, teknik, media masa, komunikasi, arsitektur, dan perencanaan bisnis.

Pada perkembangannya saat ini telah banyak praktisi Notaris yang telah memenuhi kualifikasi akademik tersebut dan menjadi pengajar pada Program Magister Kenotariatan, bahkan demi menghasilkan calon Notaris yang berkualitas beberapa Perguruan Tinggi penyelenggara program Magister Kenotariatan memberikan jabatan struktural seperti Ketua Program Studi atau Sekretaris Program Studi kepada praktisi Notaris yang menjadi Dosen pengajar di Perguruan Tinggi tersebut agar mampu menyesuaikan kurikulum pembelajaran dengan kebutuhan praktek nantinya.

Pada satu sisi pemberian jabatan struktural kepada praktisi Notaris yang menjadi Dosen pengajar tersebut sangat logis mengingat karakter Ilmu Kenotariatan sebagai ilmu yang esoterik sehingga hanya akan maksimal jika benar-benar diajarkan 
dan dikendalikan oleh yang kompeten di bidangnya, namun di sisi lain UUJN juga mengatur mengenai larangan rangkap jabatan Notaris terhadap beberapa kriteria.

\section{RUMUSAN MASALAH}

Berdasarkan uraian dalam latar belakang tersebut, maka penelitian ini didasarkan atas permasalahan sebagai berikut: Pertama, Apakah Notaris yang menjadi Dosen Yayasan Melanggar Undang-Undang Jabatan Notaris?.Kedua, Apakah Notaris dapat merangkap jabatan struktural di Perguruan Tinggi?

\section{METODE PENELITIAN}

Metode yang digunakan dalam penelitian ini adalah metode penelitian yuridis normatif yang menekankan pada norma-norma hukum dengan menganalisa peraturan perundang-undangan terkait. Dalam Penelitian ini peneliti menggunakan dua metode pendekatan masalah yaitu 1) Statute Approach, pendekatan dengan menelaah semua peraturan perundangundangan yang bersangkut paut dengan permasalahan (isu hukum) yang sedang dihadapi. 2) Conseptual Approach, yaitu pendekatan yang beranjak dari pandanganpandangan dan doktrin-doktrin yang berkembang di dalam ilmu hukum. ${ }^{1}$

\footnotetext{
${ }^{1}$ Peter Mahmud Marzuki, Penelitian Hukum, Kencana Prenada Media, Jakarta, 2010, hlm. 95-97
}

\section{PEMBAHASAN}

Prinsip Hukum Yang Menjadi Dasar Larangan Rangkap Jabatan Notaris

Berlakunya UUJN memepertegas bagaimana kewenangan dan kewajiban Notaris dalam tugas jabatannya. Selain kedua hal tersebut diatur pula mengenai larangan bagi Notaris. Mengenai larangan bagi Notaris yang telah ditentukan dalam Pasal 17 UUJN, dalam huruf c sampai dengan huruf i diatur bahwa Notaris dilarang merangkap jabatan atau pekerjaan lain, yaitu : “... c. merangkap sebagai pegawai negeri; d. merangkap jabatan sebagai pejabat negara; e. merangkap jabatan sebagai advokat; f. merangkap jabatan sebagai pemimpin atau pegawai badan Usaha milik negara, badan usaha milik daerah atau badan usaha swasta; g. merangkap jabatan sebagai Pejabat Pembuat Akta Tanahdan/atau Pejabat Lelang Kelas II di luar wilayah jabatan Notaris; h. menjadi Notaris Pengganti; ..."

Suatu profesi dapat didefinisikan secara singkat sebagai jabatan seseorang kalau profesi tersebut tidak bersifat komersial, mekanis, pertanian dan sebagainya. ${ }^{2}$ Sifat sebagaimana tersebut diatas terdapat pada Jabatan Notaris. Jabatan Notaris adalah Jabatan terhormat

${ }^{2}$ Suhrawardi K. Lubis, Etika Profesi Hukum, Sinar Grafika, Jakarta, 1994, hal. 10. 
(Officium Nobile) karena Notaris selaku Pejabat Umum merupakan jabatan kepercayaan (Vertrouwens Ambt) dan secara personal Notaris adalah seorang yang dipercaya oleh masyarakat dalam pembuatan alat bukti berupa akta Otentik (Vertrouwens Person). Disamping itu Jabatan Notaris dikatakan sebagai jabatan yang terhormat karena Notaris sebagai Pejabat Umum menjalankan sebagian kekuasaan Negara di bidang hukum privat dan khususnya mengenai pembuatan akta otentik yang mempunyai nilai pembuktian sempurna.

Menurut Abdulkadir Muhammad, dalam menjalankan jabatannya seorang Notaris diharuskan memiliki : 1) Moral, akhlak serta kepribadian yang baik. 2) Menghormati dan menjunjung tinggi harkat dan martabat jabatan Notaris. 3) Bertindak jujur, mandiri dan tidak berpihak serta penuh rasa tanggung jawab berdasarkan Perundang-Undangan dan isi sumpah jabatan Notaris. 4) Meningkatkan ilmu pengetahuan yang telah dimiliki tidak terbatas pada ilmu hukum dan kenotariatan.

5) Mengutamakan pengabdian kepada kepentingan masyarakat ${ }^{3}$

${ }^{3}$ Habib Adjie, "Politik Hukum Kenotariatan", Bahan Bacaan Mahasiswa, Program Studi Magister Kenotariatan, Fakultas Hukum Universitas Narotama Surabaya, 2014. hal. 14
Pendapat Abdulkadir di atas tak jauh berbeda dengan pendapat Ignatius Ridwan Widyadharma, yang mengacu pada cerita dialog filosof Plato "TheRepublic", bahwa seorang profesional itu harus menguasai pekerjaannya sesuai dengan kode etik mereka dan bukan sekedar pelayanan yang amburadul, maka notaris sebagai suatu profesi harus dilakukan dengan profesional. Sedangkan seseorang yang profesional itu harus melakukan spesialisasi yang artinya tidak boleh merangkap dengan pekerjaan lain. ${ }^{4}$

Begitu juga jika dikaitkan dengan pendapat Franz Magnis Suseno yang menyatakan bahwa sebagai seorang profesional hukum, Notaris harus memiliki 5 kriteria nilai moral yang kuat yang mendasari kepribadian Notaris tersebut yaitu: kejujuran, otentik, bertanggungjawab, kemandirian moral dan keberanian moral. Kelima nilai moral tersebut tentunya tak akan mungkin terpenuhi kalau Notaris masih melakukan rangkap jabatan. ${ }^{5}$

Seorang Notaris juga tidak mungkin melakukan rangkap jabatan jika dihubungkan dengan pendapat Notohamidjojo yang mengharuskan

4 Ignatius Ridwan Widyadharma, Etika Profesi Hukum Dan Keperanannya, Badan Penerbit Universitas Diponegoro, Semarang, 2001, hal. 17.

5 Franz Magnis Suseno dalam Ignatius Ridwan Widyadharma, Ibid 
seorang profesional hukum memiliki sikap manusiawi, adil, patut dan jujur. Logikanya apabila Notaris tersebut masih melakukan rangkap jabatan akan sangat susah baginya bersifat adil dan jujur. Pasti akan ada kecenderungan untuk menguntungkan salah satu pihak yang akibatnya menjadi bersikap tidak adil dan tidak jujur.

Notaris harus memenuhi syarat nama baik, kewibawaan, ketelitian, kejujuran serta integritas. Semua syarat di atas akan sangat sulit terpenuhi apabila Notaris masih melakukan rangkap jabatan. Sebagai gambaran seorang Notaris yang merangkap jabatan tentunya akan sangat sulit baginya untuk membagi waktu dengan pekerjaan sebagai notaris, kalaupun bisa pastinya pekerjaannya menjadi tidak maksimal. Disamping itu dengan melihat bagaimana tugas dari jabatan lain yang dirangkapnya tentunya akan membuat independensi dalam pekerjaan sebagai Notaris akan terganggu dan menjadi cenderung berpihak pada salah satu pihak dalam aktanya karena pasti sangat besar kemungkinan mereka akan membuat akta yang ada hubungannya dengan kantor tempatnya bekerja. Dari segi ketelitian, sangat tidak mungkin notaris bisa membuat akta dengan teliti apabila ia masih disibukkan dengan pekerjaan lain. Dengan semua pelanggaran yang ada, tentunya kewibawaan yang diharapkan ada pada seorang notaris otomatis akan hilang.

Ketentuan dalam Pasal 16 ayat 1 huruf a UUJN menyatakan dalam menjalankan tugas jabatannya Notaris wajib : "bertindak amanah, jujur, saksama, mandiri, tidak berpihak, dan menjaga kepentingan pihak yang terkait dalam perbuatan hukum" Sebagai Pejabat Umum, Notaris harus Independen. Dalam istilah sehari-hari istilah Independen ini sering disama-artikan dengan Mandiri. Dalam konsep Manajemen bahwa penerapan istilah Mandiri, berarti institusi yang bersangkutan secara manajerial dapat berdiri sendiri tanpa tergantung kepada atasannya, tetapi secara institusional tetap tergantung kepada (depend on) atasannya. Sedangkan Independen baik secara manajerial maupun insitusional tidak tergantung kepada atasannya ataupun kepada pihak lainnya.

Independen ini mempersoalkan kemerdekaan Pejabat Umum dari intervensi atau pengaruh pihak lain ataupun diberi tugas oleh instansi lain. Oleh karena itu dalam konsep Independen ini harus diimbangi dengan konsep Akuntabilitas. Akuntabilitas ini mempersoalkan keterbukaan (transparancy) menerima kritik dan pengawasan (controlled) dari luar serta bertanggungjawab kepada pihak luar 
atas hasil pekerjaannya atau pelaksanaan tugas-jabatannya.

Larangan rangkap jabatan bagi

Notaris erat kaitannya dengan prinsip profesionalitas dan prinsip kemandirian. Prinsip profesional Notaris erat kaitannya dengan jabatan Notaris merupakan jabatan kepercayaan, yaitu sebagai sosok yang dipercaya Negara untuk melayani masyarakat, sehingga untuk menjalankan jabatan Notaris diperlukan konsentrasi baik itu energi maupun pikiran agar mampu melayani masyarakat yang membutuhkan jasanya secara maksimal. Sedangkan prinsip kemandirian Notaris dapat dilihat bahwa meskipun Notaris diangkat oleh Menteri tetapi Notaris bukan subordinat dari Menteri, selain itu Notaris tidak digaji oleh Negara sehingga jelas bahwa dengan kondisi tersebut Notaris menjadi sosok yang independen atau mandiri serta bebas dari pengaruh kekuasaan baik itu eksekutif, legislatif maupun yudikatif. Dengan Notaris merangkap jabatan terlebih dalam lingkup pelaksana salah satu dari tiga unsur tersebut diatas maka kemandirian Notaris akan menjadi hilang.

Keberadaan jabatan Notaris dibutuhkan oleh masyarakat dan sebagi organ atau kepanjangan tangan pemerintah untuk menciptakan kesejahteraan dan keadilan dalam masyarakat, oleh karenanya
Notaris harus menjalankan jabatannya secara profesional, independent dan tidak memihak. Apabila terjadi Notaris merangkap jabatan yang mewakili golongan tertentu maka akan terjadi keberpihakan dan Notaris menjadi tidak lagi mandiri atau independen.

Selain itu, Larangan rangkap jabatan Notaris berkaitan erat dengan bentuk spesialisasi yang mengharuskan seorang Notaris bersikap profesional dimana salah satunya yaitu dengan berkonsentrasi pada satu profesi yang telah ia putuskan untuk ia jalani. Disamping itu larangan tersebut juga bertujuan untuk mencegah terjadinya benturan kepentingan (conflict of interest,) serta agar notaris itu tetap independen dan netral.

\section{Perbedaan Badan Usaha dan Badan Hukum}

Sebelum menganalisis tentang kedudukan Notaris yang merangkap sebagai Dosen di sebuah Yayasan maka terlebih dahulu harus ditelaah tentang kedudukan Yayasan sebagai badan hukum. Pada bagian ini akan dibahas terlebih dahulu mengenai perbedaan badan hukum dengan badan usaha.

Secara umum telah dipahamai bahwa subyek hukum adalah pendukung hak dan kewajiban yang disebut orang. Orang menurut konsep hukum terdiri atas 
manusia (naturalijk persoon) dan badan hukum (recht persoon). Manusia adalah subyek hukum menurut konsep biologis sebagai gejala alam dan sebagai mahkluk ciptaan Tuhan yang dilengkapi dengan akal, persaan dan kehendak. Sedangkan badan hukum adalah subyek hukum menurut konsep yuridis, sebagai gejala hidup bermasyarakat dan sebagai badan ciptaan manusia berdasar pada hukum yang dapat dibebani hak dan kewajiban seperti manusia. $^{6}$

Sebagaimana disebutkan diatas, badan hukum bukanlah makhluk selayaknya manusia. Badan hukum tidak mempunyai daya pikir, kehendak dan tidak mempunyai "central bewustzijn", karena badan hukum tidak dapatmelakukan perbuatan hukum sendiri. Maka dari itu untuk dapat melakukan suatu perbuatan hukum maka badan hukum harus bertindak dengan perantaraan orang-orang biasa atau manusia (natuurlijk persoon).

Ketentuan yang membatasi cara bertindak dan perantaraan ini bisa diatur dalam anggaran dasar atau undang-undang. Namun demikian, kemampuan hukum atau kekuasaan hukum dari badan hukum dalam lapangan hukum harta kekayaan pada asasnya menunjukkan persamaan dengan

${ }^{6}$ Abdulkadir Muhammad, Hukum Perdata Indonesia, Citra Aditya Bakti, Bandung, 2014, hal. 23 manusia. Tiap hukumkekayaan selain dengan tegas dikecualikan dapat berlaku pada badan hukum, yaitu dalam hukum perikatan dan kebendaan.

Dalam pergaulan hukum istilah badan hukum lazim digunakan meskipun tentang keabsahan suatu badan hukum itu masih diperdebatkan para ahli hukum. Menurut Subekti, pengertian badan hukum pada pokoknya adalah suatu badan hukum atau perkumpulan yang dapat memiliki hakhak, kewajiban-kewajiban dan melakukan perbuatan hukum seperti manusia serta memiliki kekayaan sendiri, dapat digugat dan menggugat di muka pengadilan. ${ }^{7}$

Menurut Von Savigny, badan hukumitu semata-mata buatan negara saja. Karena sebenarnya menurut hukum alam hanya manusia sajalah sebagai subyek hukum, badan hukum itu hanya merupakan fiksi saja, merupakan sesuatu yang sesungguhnya tidak ada, tapi orang menciptakan dalam bayangannya suatu pelaku hukum (badan hukum) sebagai subyek hukum diperhitungkan sama dengan manusia. Menurut teori Von Savigny tersebut ini untuk menciptakan badan

${ }^{7}$ Subekti, Pokok-Pokok Hukum Perdata, Intermasa, Jakarta, 2003, hal. 14 
hukum itu perluadanya campur tangan penguasa. ${ }^{8}$

Pendapat mengenai badan hukum juga dikemukakan oleh Holder dan Binder melalui teori harta karena jabatan atau teori von het ambetelijk vermogen, bahwa badan hukum adalah suatu badan yang mempunyai harta yang berdiri sendiri, yang dimiliki oleh badan hukumitu tetapi oleh pengurusnya dan karena jabatannya ia diserahi tugasuntuk mengurus harta tersebut. ${ }^{9}$

Mengenai unsur-unsur dari suatu badan hukum menurut doktrin yang hingga kini diterima, Ali Ridho mengemukakan bahwa badan hukum terdiri atas unsur sebagai berikut :a) Adanya harta kekayaan yang terpisah;b) Mempunyai tujuan tertentu;c) Mempunyai kepentingan sendiri; dand) Adanya organisasi yang teratur ${ }^{10}$

Unsur lain yang dapat dijadikan kriteriasebagai badan hukum dapat pula dilihat dari prosedur pendiriannya dan apa yang secara khusus disyaratkan oleh undang-undang. Untuk mendirikan badan hukum seperti yayasan selain memenuhi kriteria tersebut di atas, juga harus memenuhi persyaratan formil yang ditentukan oleh undang-undang dalam hal

${ }^{8}$ Von Savigny dalam Marhainis Abdul Hay, Hukum Perdata Material, Pradnya Paramita,Jakarta, hal. 34. Hay, Ibid ini adalah didirikan denganakta notaris dan pengesahan oleh pemerintah.

Badan hukum (rechtpersoon)

dibedakan menjadi dua bentuk yaitu, Badan hukum publik dan badan hukum privat. Badan hukum publik, adalah badan hukum yang didirikan berdasarkan hukum publik atau yang menyangkut kepentingan publik, orang banyak atau negara. Badan hukum ini merupakan badan-badan negara dan mempunyai kekuasaan wilayah atau merupakan lembaga yang dibentukoleh yang berkuasa berdasarkan perundangundangan yang dijalankan secara fungsional oleh eksekutif atau pemerintah atau badan pengurus yang diberikan tugas untuk itu. ${ }^{11}$ Contoh Badan Hukum Publik adalah Bank Indonesia yang didirikan berdasar Undang-Undang No. 13 Tahun 1968.

Sedangkan Badan Hukum Privat, adalah badan hukum yang dibentuk berdasar hukum perdata yang menyangkut kepentingan pribadi orang di dalam badan hukum itu. Badan hukum ini merupakan badan swasta yang didirikan oleh pribadi orang atau badan hukum untuk tujuan tertentu seperti mencari keuntungan, kegiatan sosial pendidikan, ilmu

${ }^{10}$ R. Ali Ridho, Hukum Dagang tentang Aspek-Aspek Hukum dalam Asuransi Udara, Asuransi Jiwa dan Perkembangan Perseroan Terbatas, Remadja Karya, Jakarta, 1986, hal. 303.

${ }^{11}$ Abdulkadir Muhammad, Op. Cit., hal. 26 
pengetahuan, politik, kebudayaan dan lainlain yang sesuai menurut hukum. ${ }^{12}$ Contoh Badan Hukum Privat antara lain Yayasan, Perseroan Terbatas, Koperasi danPerkumpulan

Menurut Abdulkadir Muhammad, berdasarkan eksistensinya badan hukum diklasifikasikan menjadi 3 (tiga) golongan, yaitu : 1) Badan Hukum yang dibentuk oleh pemerintah (penguasa negara), yaitu badan hukum untuk kepentingan negara dalam menjalankan pemerintahan. 2) Badan Hukum yang diakui oleh pemerintah (penguasa negara), yaitu badan hukum yang bertujuan untuk memperoleh keuntungan atau kesejahteraan masyarakat melalui kegiatan usaha tertentu, seperti perseroan terbatas dan koperasi. Badan hukum ini merupakan badan hukum yang profit oriented atau disebut juga dengan badan usaha. 3) Badan Hukum yang diperbolehkan atau untuk suatu tujuan tertentu yang bersifat ideal, yaitu badan hukum yang tidak bertujuan mencari keuntungan dan hanya menjalankan kegiatan pendidikan, sosial, keagamaan dan kemanusiaan. Badan hukum ini merupakan badan hukum yang non profit oriented. ${ }^{13}$

\footnotetext{
${ }^{12}$ Ibid

${ }^{13}$ Ibid, hal. 24-25

14 Endra Murti Sarogo, "Bentuk Badan Usaha”, http://staffnew.uny.ac.id/upload/19850409
}

Dari kualifikasi badan hukum tersebut diatas salah satunya merupakan badan usaha. Badan usaha adalah kesatuan yuridis (hukum), teknis, dan ekonomis yang bertujuan mencari laba/keuntungan. 14 Tujuan mencari laba tersebut sesuai dengan esensi dari kata "usaha" sehingga dengan demikian jelas bahwa badan usaha sudah pasti dijalankan untuk mencari keuntungan. Jenis badan usaha tersebut antara lain Unit Dagang (UD), Comanditer Venotshap (CV), Firma, Perkumpukan dan Perseroan Terbatas (PT).

Menurut Abdulkadir Muhammad, Perusahaan adalah setiap bentuk usaha yang menjalankan setiap jenis usaha yang bersifat tetap, terus menerus, dan didirikan, bekerja serta berkedudukan dalam wilayah negara Indonesia dengan tujuan memperoleh keuntungan dan atau laba. Sementara yang dimaksud dengan "bentuk usaha" adalah organisasi usaha atau badan usaha yang menjadi wadah penggerak setiap jenis usaha. Organisasi atau badan usaha tersebut diatur/diakui oleh undangundang, baik bersifat perseorangan, persekutuan atau badan hukum. ${ }^{15}$

Meskipun secara arti badan usaha berbeda dengan perusahaan, namun

2010121005/pendidikan/Materi+Bisnis+(Bentuk+B adan+Usaha).pdf

${ }^{15}$ Abdul Kadir Muhammad, Ibid, hal.1 
terdapat hubungan erat yaitu badan usaha merupakan penggerak dari perusahan. Kegiatan perusahaan tidak dapat dilepaskan dari bentuk badan usaha dan perizinan yangdiperlukan untuk menjalankan usaha tersebut. Suatu badan usaha dapat dijalankan dengan berbadan hukum ataupun tidak berbadan hukum. Badan usaha yang berbadan hukum tersebut dapat berupa Perseroan Terbatas atau Perkumpulan, sedangkan badan usaha yang tidak berbadan hukum antara lain UD, CV dan Firma.

Kedudukan badan usaha yang berbadan hukum dalam hal ini tentunya akan berbeda dengan kedudukan badan usaha yang tidak berbadan hukum. Jika suatu badan usaha sudah berbadan hukum maka badan usaha tersebut dapat diperlakukan selayaknya manusia sebagai subyek hukum dan memiliki kekayaan yang terpisah dari kekayaan pendiri badan usaha.

Dari uraian diatas dapat dilihat adanya perbedaan antara badan hukum dengan badan usaha. Badan hukum merupakan subyek hukum selain manusia yang dapat dibebani hak dan kewajiban serta terbentuk berdasarkan hukum yang berlaku. Badan hukum tersebut dapat berupa badan hukum profit oriented dan dapat berupa badan hukum non profit orientedatau nirlaba. Sedangkan badan usaha adalah organisasi atau badan yang menjadi wadah penggerak setiap jenis usaha. Badan usaha tersebut terbagi atas badan usaha yang berbadan hukum dan badan usaha yang tidak berbadan hukum.

\section{Kedudukan Notaris Yang Menjadi Pegawai Yayasan Sebagai Dosen}

Pasal 17 ayat (1) UUJN telah mengatur secara tegas mengenai larangan rangkap jabatan bagi Notaris. Ketentuan dalam Pasal 17 ayat (1) huruf f UUJN yang menyatakan Notaris dilarang : "f. merangkap jabatan sebagai pemimpin atau pegawai badan usaha milik negara, badan usaha milik daerah atau badan usaha swasta;...”. Terhadap rumusan larangan rangkap jabatan yang ditentukan dalam Pasal tersebut harus dipahami bahwa larangan yang berlaku adalah apabila Notaris merangkap sebagai pemimpin atau pegawai badan usaha baik milik pemerintah maupun swasta.

Yang dimaksud pemimpin badan usaha pada pasal tersebut adalah orang yang mengendalikan suatu badan usaha. Sedangkan yang dimaksud pegawai adalah Orang pribadi yang bekerja pada pemberi kerja, berdasarkan perjanjian atau kesepakatan kerja baik secara tertulis maupun tidak tertulis, untuk melaksanakan suatu pekerjaan dalam jabatan atau kegiatan tertentu dengan memperoleh imbalan yang 
dibayarkan berdasarkan periode tertentu, penyelesaian pekerjaan, atau ketentuan lain yang ditetapkan pemberi kerja, termasuk orang pribadi yang melakukan pekerjaan dalam jabatan negeri.

Secara esensi yang disebut pegawai memiliki kesamaan dengan pekerja sebagaimana disebutkan dalam Pasal 1 angka 3 Undang-Undang Nomor 13 Tahun 2003 tentang Ketenagakerjaan, yang menyebutkan: "Pekerja/buruh adalah setiap orang yang bekerja dengan menerima upah atau imbalan dalam bentuk lain", atau pada beberapa bidang yang lain disebut juga dengan karyawan. Baik pegawai, pekerja ataupun karyawan memiliki kesamaan yaitu bekerja pada pemberi kerja dan mendapatkan imbalan berupa upah, namun penyebutannya seringkali digunakan berbeda. Kata pegawai umumnya digunakan untuk menyebut mereka yang bekerja pada instansi pemerintahan, kata karyawan digunakan untuk menyebut mereka yang bekerja pada perusahaan swasta dan kata pekerja digunakan untuk mereka yang bekerja di pabrik atau bekerja pada perseorangan pemberi kerja.

Kedudukan Notaris yang bekerja menjadi dosen pada suatu Yayasan seringkali menjadi perdebatan terkait

${ }^{16}$ Riduan Syahrani, Seluk Beluk Dan AsasAsas Hukum Perdata, Alumni, Bandung, 1985, hal. 54 apakah hal tersebut merupakan pelanggaran terhadap UUJN yang dilakukan oleh Notaris karena merangkap jabatan. Notaris yang menjadi Dosen pada suatu Yayasan tentunya secara otomatis menjadi pegawai Yayasan karena dari kegiatan mengajar yang dilakukan tersebut akan diperoleh upah atau imbalan.

Pada posisi ini haruslah dibedakan antara badan hukum dengan badan usaha. Badan hukum merupakan organisasi, perkumpulan atau paguyuban lainnya yang legalitas pendiriannya dengan akta otentik dan oleh hukum diperlakukan sebagai subyek hukum. 16 Sedangkan yang dimaksud dengan badan usaha adalah organisasi yang menjalankan kegiatan usaha dengan tujuan mencari keuntungan.

Badan hukum dapat didirikan dengan tujuan mencari laba seperti pada Perseroan Terbatas ataupun dengan tujuan nirlaba seperti yayasan. Berdasarkan ketentuan Pasal 60 UU Sisdiknas telah ditentukan bahwa PTS didirikan oleh badan penyelenggara berbadan hukum yayasan atau perkumpulan. Baik yayasan maupun perkumpulan merupakan badan hukum tetapi bukan badan usaha karena adanya tujuan nirlaba atau tidak mencari keuntungan. 
Kedudukan Yayasan sebagai badan hukum nirlaba dan bukan sebagai badan usaha membawa konsekuensi bahwa segala yang terdapat dalam sistem organisasi Yayasan baik itu pemimpin maupun pegawainya tidak dapat disebut sebagai pemimpin badan usaha atau pegawai badan usaha. Sehingga dengan demikian rumusan larangan rangkap jabatan dalam Pasal 17 ayat (1) huruf f UUJN tidak terpenuhi.

Secara tujuanpun dapat dibedakan pada saat Notaris menjalankan jabatannya sebagai Pejabat Umum dan pada saat Notaris menjadi Dosen. Pada saat Notaris menjalankan tugas jabatannya sebagi Notaris maka hal ini adalah menjadi kewajiban sesuai dengan sumpah jabatan yang pernah diucapkan Notaris sebelum menjalankan jabatannya. Sedangkan pada saat menjadi Dosen pada suatu Yayasan adalah merupakan bentuk pengabdian dari Notaris pada Bangsa dan Negara serta dalam rangka mengamalkan keilmuan yang dimilikinya.

Tugas pokok dari Dosen adalah memberikan atau menyampaikan ilmu pengetahuan yang dimilikinya kepada mahasiswanya. Notaris yang secara umum dipandang sebagai begawan dalam hukum privat karena tugasnya menjalankan sebagian urusan pemerintah di bidang hukum privat, pada saat menjadi dosen diharapkan mampu menyalurkan ilmu yang dimilikinya kepada mahasiswa, khususnya pada mahasiswa program kenotariatan.

Salah satu tujuan bangsa Indonesia sebagaimana disebutkan dalam alenia keempat Undang-Undang Dasar Negara Republik Indonesia Tahun 1945 adalah untuk mencerdaskan kehidupan bangsa. Tujuan tersebut wajib dilaksanakan oleh seluruh Warga Negara Indonesia sehingga dengan apabila seorang Notaris juga menjadi Dosen maka hal tersebut dapat dipandang sebagai upaya untuk berpartisipasi dalam usaha mencerdaskan kehidupan bangsa.

Dari uraian sebagaimana telah disebutkan diatas maka jelas bahwa Notaris yang menjadi Dosen pada sebuah Yayasan tidak melanggar UUJN karena kedudukan Yayasan adalah sebagai badan hukum nirlaba atau bukan merupakan badan usaha. Disamping itu harus dilihat pula manfaat yang diberikan apabila Notaris menjalankan juga profesi Dosen adalah demi mencerdaskan kehidupan bangsa khususnya dalam keilmuan yang berkaitan dengan dunia kenotariatan karena ilmu kenotariatan adalah ilmu yang esoterik.

\section{Rangkap Jabatan Notaris Sebagai Pejabat Struktural Perguruan Tinggi}

Karakteristik ilmu Kenotariatan sebagai ilmu yang esoterik membawa 
konsekuensi bahwa ilmu tersebut tidak bisa diajarkan oleh sembarang orang. Hal ini membuat hampir di semua Perguruan Tinggi penyelenggara Program Studi Magister Kenotarian menggunakan Dosen dari kalangan Notaris untuk Program Studi ini demi menghasilkan calon-calon Notaris yang berkualitas. Kualitas calon Notaris inilah yang menjadi daya jual dari Peguruan Tinggi penyelenggara Program Magister Kenotariatan. Semakin berkualitas lulusannya maka akan semakin banyak pula calon-calon mahasiswa yang tertarik untuk mendaftar di Perguruan Tinggi tersebut.

Demi menjaga kualitas lulusan dan demi mampu bersaing di tengah menjamurnya Program Magister Kenotariatan di Indonesia banyak Perguruan Tinggi yang menempatkan Notaris dalam Jabatan Struktural pada Perguruan Tinggi tersebut. Dengan ditempatkannya seorang Notaris pada Jabatan Struktural dalam Perguruan Tinggi, diharapkan Notaris tersebut mampu memimpin jalannya program pendidikan Kenotariatan dan mampu merancang suatu kurikulum untuk pendidikan kenotariatan yang sesuai dengan kebutuhan praktek. Notaris yang menduduki Jabatan Struktural tersebut diharapkan mampu memberikan solusi karena sampai dengan saat ini belum ada keseragaman kurikulum tentang pendidikan kenotariatan di Indonesia.

Keadaan sebagaimana tersebut diatas menimbulkan pro dan kontra baik dikalangan akademisi maupun dikalangan Notaris sendiri. Sebagian mendukung dengan alasan untuk menghasilkan Notaris yang berkualitas dan memiliki daya saing di tengah perkembangan jaman maka penididikan Kenotariatan harus dipegang oleh Notaris sendiri sehingga menempatkan Notaris dalam suatu Jabatan Struktural dalam Perguruan Tinggi adalah wajar. Sementara di pihak yang kontra terhadap kondisi tersebut berpendapat bahwa Notaris jelas dilarang untuk merangkap jabatan sebagaimana telah diatur dalam UUJN dan dengan merangkap jabatan akan berseberangan dengan karakteristik Jabatan Notaris sebagai Profesional. Pendapat mengenai larangan Notaris untuk merangkap Jabatan Struktural dalam Perguruan Tinggi tersebut bisa salah dan bisa juga benar tergantung status Dosen dari Notaris itu sendiri.

Jika dilihat dari Pasal 17 ayat (1) huruf c UUJN dapat dilihat ketentuan mengenai larangan rangkap jabatan bagi Notaris terdapat ketentuan bahwa Notaris dilarang : "c. merangkap sebagai pegawai negeri;..."Terhadap ketentuan dalam tersebut kedudukan Notaris yang memiliki 
Jabatan Struktural dalam Perguruan Tinggi masih harus dibedakan status Perguruan Tinggi tersebut PTN atau PTS. Jika PTS tentunya rumusan larangan rangkap jabatan tersebut tidak terpenuhi karena Jabatan Struktural dalam PTS maupun Dosen pada PTS bukanlah Pegawai Negeri. Namun jika PTN maka terlebih dahulu harus dilihat Notaris tersebut menjadi Dosen dengan Status Dosen PNS atau Dosen Non PNS. Dalam posisi ini hampir tidak dimungkinkan seorang Dosen Non PNS dapat memiliki Jabatan Struktural dalam PTN sehingga apabila Notaris menduduki Jabatan Struktural dalam PTN maka bisa jadi Notaris tersebut adalah Dosen PNS. Jika Notaris tersebut menjadi Dosen dengan status Dosen PNS maka rumusan tersebut terpenuhi dan Notaris telah melanggar larangan dalam UUJN

Poin penting larangan rangkap jabatan Notaris yang memilki jabatan struktural dalam Perguruan Tinggi adalah pada status Dosennya. Notaris yang menjadi Dosen dan memiliki jabatan struktural dalam Perguruan Tinggi tentunya harus memiliki nomor registrasi pendidik. Pada titik inilah pelanggaran terhadap UUJN rawan terjadi.

Pada bagian sebelumnya telah dijelaskan bahwa tenaga pendidik pada Perguruan Tinggi harus memiliki nomor registrasi baik itu berupa NIDN, NIDK atau NUP. Hal inilah yang harus dipahami oleh Notaris pada saat menjadi Dosen atau memiliki jabatan struktural dalam Perguruan Tinggi maka Notaris tidak tepat apabila memiliki NIDN. Hal tersebut berkaitan dengan kewajiban pemegang NIDN yang telah ditentukan dalam Pasal 5 ayat (1) huruf a dan huruf b Permenristekdikti 26/2015 untuk bekerja penuh waktu 40 (empat puluh) jam setiap minggu danmelaksanakan Tridharma Perguruan Tinggi dengan beban kerja paling sedikit sepadan dengan 12 (dua belas) sks pada setiap semester.

Terhadap ketentuan mengenai kewajiban Tridharma Perguruan Tinggi masih sangat memungkinkan untuk dipenuhi apabila Notaris memilki jabatan struktural dalam Perguruan Tinggi. Pada suatu jabatan struktural dihitung paling rendah adalah sama dengan 4 sks, sehingga hanya dibutuhkan 8 sks tambahan untuk memenuhi kewajiban tersebut yang dapat dipenuhi dari 6 sks kegiatan pembelajaran dan 2 sks dari kegiatan penelitian. Namun pada kewajiban untuk bekerja penuh selama 40 jam per minggu hampir pasti tidak dapat terpenuhi. Kewajiban untuk bekerja 40 jam per minggu sama dengan kewajiban bekerja selama 8 jam perhari. Bagi Notaris yang menjalankan tugas jabatan untuk melayani 
masyarakat hampir tidak mungkin untuk meninggalkan kantornya selama 8 jam per hari.

Pasal 16 ayat (1) huruf a UUJN telah mewajibkan Notaris untuk bertindak jujur. Hal serupa juga diatur dalam Pasal 4 ayat (2) UUJN bahwa sebelum menjalankan jabatannya Notaris terlebih dahulu mengucapkan sumpah dan pada salah satu bagian sumpah tersebut Notaris melafalkan bahwa Notaris akan menjalankan jabatan dengan jujur. Jika dikaitkan dengan kondisi diatas maka terpenuhi atau tidaknya kewajiban untuk bekerja dalam Perguruan Tinggi selama 40 jam per minggu akan sangat berkaitan dengan hati nurani dan kejujuran dari Notaris.

Apabila dapat dibuktikan bahwa Notaris yang memiliki jabatan struktural dalam Perguruan Tinggi dan memegang NIDN tidak mampu memenuhi kewajiban sebagaimana tersebut diatas, dapat dikatakan Notaris telah melakukan pelanggaran karena tidak menjalankan kewajiban untuk bertindak jujur. Atas pelanggaran tersebut Notaris dapat dijatuhi sanksi sebagaimana diatur dalam Pasal 16 ayat (11) UUJN yang menyatakan : "Notaris yang melanggar ketentuan sebagaimana dimaksud pada ayat (1) huruf a sampai dengan huruf 1 dapat dikenai sanksi berupa:a. peringatan tertulis; $b$. pemberhentian sementara;c. pemberhentian dengan hormat; ataud. pemberhentian dengan tidak hormat."

Jika dicermati, Permenristekdikti 26/2015 sebenarnya telah memberikan kemudahan bagi kalangan profesional seperti Notaris untuk menjadi Dosen atau bahkan menduduki jabatan struktural dalam Perguruan Tinggi melalui adanya NIDK. Dengan memegang NIDK maka Notaris dapat bekerja paruh waktu dalam Peguruan Tinggi dan beban mengajarnya hanya minimal 4 sks saja dalam satu semester per tahun. Kemudahan ini sudah semestinya digunakan oleh Notaris yang merangkap sebagai Dosen atau memiliki Jabatan Struktural dalam Perguruan Tinggi.

\section{PENUTUP}

Lahirnya ketentuan mengenai larangan bagi Notaris untuk rangkap jabatan adalah untuk menghindari terjadinya konflik kepentingan (conflict of interest). Notaris yang merangkap sebagai Dosen pada sebuah Yayasan tidak melanggar ketentuan dalam Pasal 17 ayat (1) huruf f UUJN karena Yayasan bukan merupakan badan usaha. Yayasan sesuai dengan tujuan pendiriannya adalah merupakan badan hukum nirlaba yang bergerak di bidang pendidikan, sosial, keagamaan dan kemanusiaan. Kedudukan Yayasan sebagai badan hukum nirlaba dan 
bukan sebagai badan usaha membawa konsekuensi bahwa segala yang terdapat dalam sistem organisasi Yayasan baik itu pemimpin maupun pegawainya tidak dapat disebut sebagai pemimpin badan usaha atau pegawai badan usaha. Salah satu tujuan bangsa Indonesia sebagaimana disebutkan dalam alenia keempat Undang-Undang Dasar Negara Republik Indonesia Tahun 1945 adalah untuk mencerdaskan kehidupan bangsa. Tujuan tersebut wajib dilaksanakan oleh seluruh Warga Negara Indonesia sehingga dengan apabila seorang Notaris juga menjadi Dosen maka hal tersebut dapat dipandang sebagai upaya untuk berpartisipasi dalam usaha mencerdaskan kehidupan bangsa.

Notaris dapat merangkap sebagai dosen dan memiliki jabatan struktural di Perguruan Tinggi dengan ketentuan : a) Notaris dapat merangkap jabatan struktural dalam Perguruan Tinggi Swasta karena Perguruan Tinggi Swasta didirikan oleh badan penyelenggara berbadan hukum Yayasan. Yayasan merupakan badan hukum nirlaba dan bukan merupakan badan usaha sehingga Notaris tidak melanggar Pasal 17 ayat (1) huruf f UUJN. b)Notaris dapat merangkap jabatan struktural di Perguruan Tinggi Swasta dengan memiliki NIDK terlebih dahulu. Notaris tidak diperbolehkan memiliki NIDN karena beban kerja pemegang NIDN selama 40 jam dalam satu minggu tidak dapat dipenuhi oleh Notaris.

Larangan rangkap jabatan yang sudah jelas diatur dalam UUJN hendaknya diperhatikan oleh Notaris agar Notaris mampu menjalankan tugas jabatan secara profesional dan mampu melayani masyarakat yang membutuhkan jasanya dengan penuh tanggung jawab.Notaris yang memegang NIDN hendaknya segera mengganti Nomor Registrasi Pendidiknya menjadi NIDK agar mampu menjalankan tugas jabatan secara jujur sebagaimana telah diamanatkan oleh UUJN.

\section{DAFTAR PUSTAKA}

Abdulkadir Muhammad, Hukum Perdata Indonesia, Citra Aditya Bakti, Bandung, 2014.

Endra Murti Sarogo, "Bentuk Badan Usaha", http://staffnew.uny.ac.id/upload/19 850409 2010121005/pendidikan/Materi+Bi snis+(Bentuk+Badan+Usaha).pdf

Habib Adjie, "Politik Hukum Kenotariatan", Bahan Bacaan Mahasiswa, Program Studi Magister Kenotariatan, Fakultas Hukum Universitas Narotama Surabaya, 2014.

Ignatius Ridwan Widyadharma, Etika Profesi Hukum Dan Keperanannya, Badan Penerbit Universitas Diponegoro, Semarang, 2001.

Marhainis Abdul Hay, Hukum Perdata Material, Pradnya Paramita,Jakarta. 
Peter Mahmud Marzuki, Penelitian Hukum, Kencana Prenada Media, Jakarta, 2010.

R. Ali Ridho, Hukum Dagang tentang Aspek-Aspek Hukum dalam Asuransi Udara, Asuransi Jiwa dan Perkembangan Perseroan Terbatas, Remadja Karya, Jakarta, 1986.

Riduan Syahrani, Seluk Beluk Dan AsasAsas Hukum Perdata, Alumni, Bandung, 1985.

Subekti, Pokok-Pokok Hukum Perdata, Intermasa, Jakarta, 2003.

Suhrawardi K. Lubis, Etika Profesi Hukum, Sinar Grafika, Jakarta, 1994. 
